\title{
Acute Obstructive Abdomen Secondary to Intestinal Lipoma Intussusception
}

Milena Braga Soares da Silva ${ }^{1}$, Willams Germano Bezerra Segundo ${ }^{2}$, Giulia Caliolo Ierardi ${ }^{3}$, Leandro Mariano da Silva ${ }^{1}$, Gustavo de Oliveira $^{1}$, Kaline Fortes Viana ${ }^{1}$, Isaac Jose Felippe Correa Neto ${ }^{4}$, Laercio Robles ${ }^{5}$

${ }^{1}$ Coloproctology Residents at Hospital Santa Marcelina, São Paulo - SP

${ }^{2}$ Medical Student of Faculty Santa Marcelina, São Paulo - SP

${ }^{3}$ Resident of General Surgery at the Hospital Santa Marcelina, São Paulo - SP

${ }^{4}$ Coloproctology Assistant Physician at the Hospital Santa Marcelina, São Paulo - SP

${ }^{5}$ Head physician of the General Surgery department and the Coloproctology service at Hospital Santa Marcelina, São Paulo - SP

*Corresponding Author: Isaac Jose Felippe Correa Neto, Coloproctology Assistant Physician at the Hospital Santa Marcelina, São Paulo - SP.

Received date: August 14, 2020; Accepted date: September 04, 2020; Published date: September 07, 2020

Citation: M d Silva, W G B Segundo, G C Ierardi, L M d Silva, G d Oliveira1. (2020) Acute Obstructive Abdomen Secondary to Intestinal Lipoma Intussusception. International Journal of Clinical Case Reports and Reviews. 3(4); DOI: 10.31579/2690-4861/050

Copyright: (c) 2020 Isaac Jose Felippe Correa Neto, This is an open-access article distributed under the terms of the Creative Commons Attribution License, which permits unrestricted use, distribution, and reproduction in any medium, provided the original author and source are credited.

\section{Abstract}

Introduction: Intestinal intussusception corresponds to invagination of one segment inside another. Although rare in adults, it corresponds to $1 \%$ of cases involving intestinal obstruction, being more common in the small intestine. The objective of this study is to report a case of intestinal intussusception secondary to lipoma. Case Report: female patient 51 years was admitted to the emergency room with a colicky abdominal pain for 1 month, no irradiation, and with worsening for 2 days, associated with nausea, vomiting and hematochezia. On physical examination, distended and hypertympanic abdomen with pain to palpation and rectal touch with melena was observed. Acute abdominal X-ray demonstrated evidence of colonic loop dilation and hydro-air level. Computed tomography examination of abdomen and pelvis demonstrated a target lesion suggesting intussusception, confirmed in the intraoperative by invagination from the terminal ileum to the proximal descending colon with subtotal colectomy and terminal ileostomy. Discussion: Intussusception in adults usually occurs secondary to a point of advance, either by benign tumors, malignant or motility disorders. In the large intestine, lipoma is considered a rare cause of invagination, and malignant tumors are more common, and its symptomatology and risks of complications are mainly related to the size of the lesion. Conclusion: The colic submucosal intraluminal lipoma is a rare cause of intestinal intussusception and is usually an intraoperative diagnosis.

Key words: intestinal obstruction; colon lipoma; intestinal intussusception; surgical treatment

\section{Introduction}

Intestinal intussusception corresponds to invagination of one segment inside another, and $95 \%$ of the cases affects children. Although it is rare in adults, it corresponds to $1 \%$ of intestinal obstructions, being more common in the small intestine than in the coarse $[1,2]$.

In $90 \%$ of the cases, the etiology is identified by imaging studies, and the most common cause of invagination of the small intestine is benign lesions, especially lipoma, leiomyoma, hemangioma, Meckel's diverticulum, among others. In the large intestine, the most common cause is malignant neoplasms, which corresponds to $65 \%$ of cases [1, 3].

The exact trigger mechanism is still unknown, but injuries or irritations in the intestinal wall are believed to alter peristalsis, precipitating the process of invagination $[1,4,5,6]$.

The objective of this study is to present a case of intestinal intussusception secondary to lipoma in a female patient with acute obstructive abdomen.

\section{Case Report}

MBS, 51-year-old female, admitted to the surgical emergency room with a history of diffuse colicky abdominal pain for a month and no irradiation, with worsening for 2 days, associated with nausea, bilious vomiting after eating and hematochezia in small amounts. In physical examination, she was in a regular general state, dehydrated $1+/ 4+$, with vital signs within the parameters of normality, flaccid abdomen, slightly distended, with increased hydro-aerial noises, hypertympanic and painful to the mesogastric palpation without signs of peritoneal irritation, besides rectal touch with melena.

Complementary tests showed $\mathrm{Hb} 13.1 \mathrm{~g} / \mathrm{dl}$, Ht 39.8\%, Leukocytes $11,500 / \mathrm{mm} 3$ (75.5\% segmented), 418,300/mm3 platelets, urea $82 \mathrm{mg} / \mathrm{dL}$, creatinine $1.24 \mathrm{mg} / \mathrm{dL}$, Protein C Reactive $157.3 \mathrm{mg} / \mathrm{L}$, ions within the normal range. Imaging of the abdomen revealed an obstructive pattern with dilation of loop of the large intestine and hydroair level. Computed Tomography of the abdomen and the pelvis showed a lesion in target that suggested transverse colon intussusception (Figure 1 and 2) confirmed in the intraoperative by invagination from the terminal ileum to the proximal descending colon. A subtotal colectomy and terminal ileostomy were performed (Figure 3). Patient was discharged in the 5th postoperative period.

Anatomopathological study evidenced tumoration in the large intestine measuring $7.0 \times 6.5 \mathrm{~cm}$ located in cecum next to the ileocecal valve compatible with submucosal lipoma. 


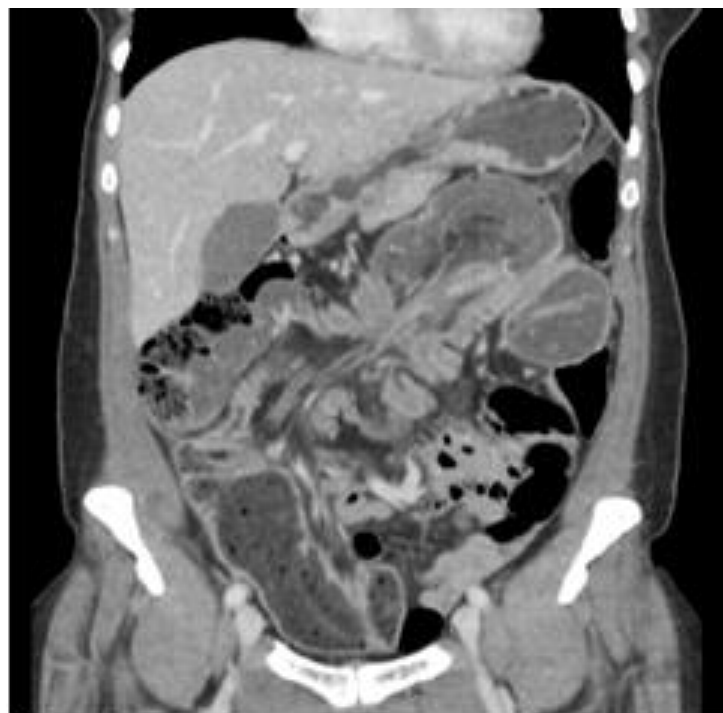

Figura 1. TC coronal section of ileo-colic intussusception.

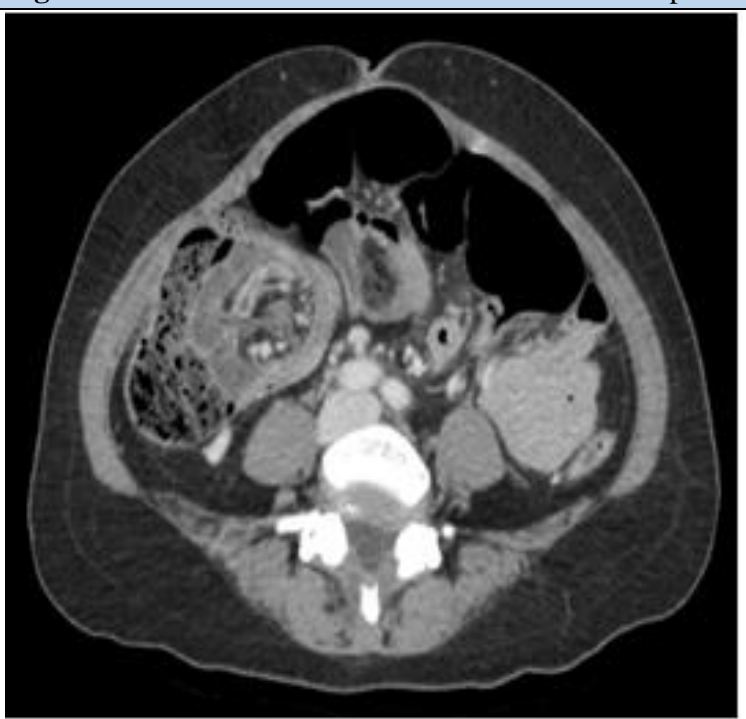

Figura 2. TC axial section of intussusception ileo-colic

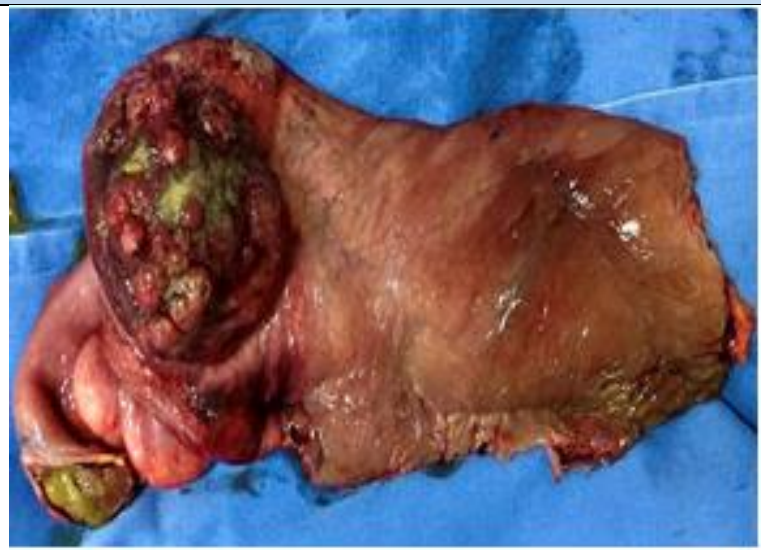

Figura 3. Intussusception photo with visualization of lipomatous lesion

\section{Discussion}

Intussusception can occur in the absence of a point of advancement, more common in children and in the small intestine, being considered primary. In adults, it occurs more rarely, usually with the presence of a advancement point and presents as inflammatory disease, benign or malignant tumors, and motility disorders as causes [7, 8].

The exact mechanism of action that precipitates intussusception is uncertain, but it is believed that an injury or irritation in the intestinal wall may alter the normal peristalsis and result in an invagination process [1, 9].There are four main types, which are differentiated by location:

1. involving slender handles;

2. colon handles only;

3. ileocolic, involving terminal ileum and ascending colon and;

4. ileocecal, involving the ileocecal valve and ceco[10,11,12].

Most colon invaginations result from malignant lesions, especially adenocarcinoma and lymphoma [14], corresponding to $65 \%$ of cases. When it comes to benign tumors, lipoma appears as a rare cause, with an incidence of 0.2 to $4.4 \%$ throughout the world. Despite this, it is the third most common benign tumor in the large intestine, being less prevalent only than hyperplastic polyps and adenomatous [15].

Colon lipomas are more frequent in women, with a higher incidence between $5^{\circ}$ and $6^{\circ}$; decades of life $[1,4,5,6,16,17]$. The most common sites are cecum and ascending colon, with a prevalence rate of $61 \%$ of cases $[1,4,5,6,14]$. Similarly, the case presented here, regarding age and location, are typically asymptomatic, and are commonly found incidentally during a colonoscopy, intraoperative or autopsies [15].The symptomatology is related to the complications and size of the lipoma and occurs in about $25 \%$ of cases [3]. Those with more than $2 \mathrm{~cm}$ may cause intestinal obstruction without intussusception, and those above $4 \mathrm{~cm}$, similar to that reported, are considered giant and more commonly related to intussusception $[3,5,6,18]$

Computed tomography is considered the gold standard for the diagnosis of intussusception, and spherical or ovoid mass with internal lesions of thin septa with homogeneous content [2].

In most cases, involving adults, the treatment is eminently surgical, due to the possibility in up to $65 \%$ of cases of association with malignant lesions [1]. There are controversies regarding the preliminary options for reduction of intussusception before resection $[13,16]$ but the reduction should not be attempted if there are signs of ischemia or intestinal perforation, besides having its indication related to the location of intussusception $[1,2,5]$

Our case presents an uncommon manifestation for an ileo-colic intussusception, in which the patient presented an intramuscular lipoma causing small bowel invagination that extended to the descending colon, demonstrating the relevance of the surgical treatment.

\section{Conclusion}

Colic submucosal intraluminal lipoma is a rare cause of intestinal intussusception and is generally diagnosed intraoperatively, as in the case reported.

\section{References}

1. Neto IJFC,Werck AJ, Cecchinni ARS, Lopes EA, Watte HH, Souza RFL, et al. (2016) Intussepção colônica em adultos: relatório de duas apresentações clinicas. Colorec Cancer.2:19

2. M'rabet S, Jarrar MS, Akkari I, et al. (2018) Intussuscepção colônica causada por lipoma sigmoidal: relato de caso. Int $\mathbf{J}$ SurgRep . 50:1-4.

3. Cordeiro J, Cordeiro L, Pôssa P, Candido P, Oliveira A, et al. (2019) Intestinal intussusception related to colonic pedunculated lipoma:A case report and review of the 
literature. International Journal of Surgery Case Reports. 55: 206-209

4. Tan KY, Tan SM, Tan AG, Chen CY, Chng HC, Hoe MN. (2003) Adultintussusception: experience in Singapore. ANZ J Surg. 73:1044-1047.

5. Hanan B, DinizTR, Luz MMP, ConceiçãoSA, Silva RG, Filho LA. (2007) Intussuscepção intestinal emadultos. Rev bras. Colo-proctol. 27(4): 432-438.

6. Paškauskas S, Latkauskas T, Valeikaitğ G,Paršeliūnas A, Švagždys S, Saladžinskas Z, et al. (2010) Colonicintussusceptioncausedbycolonic lipoma: a case report. Medicina (Kaunas).46:477-481.

7. Ongom PA, Kijjambu SC. (2013) Intussuscepção em adultos: um complexo clínico que revela continuamente o tratamento de doenças agudas (emergenciais) e crônicas. OA Emergency Medicine.1 (1):3.

8. Yalamarthi S, Smith RC. (2005) Adult intussusception: case reports and review of literature. Postgrad Med J. 81:174-177.

9. Chien HW, Wu CH, Tsai MY, Teng YH. (2009) Intussuscepção de adultosInduzidopor adenocarcinoma do cólon: relato de caso. J EmergCrit Care Med. 20: 221-224.

10. Mohamed M, Elghawy K, Scholten D, Wilson K, McCann M. (2015) Adultsigmoidorectalintussusceptionrelatedtocolonic lipoma: A rare case reportwithanatypicalpresentation. Int J Surg Case Rep.10:134-137.

11. Balamoun H, Doughan S. (2011) Ileal lipoma - a rare cause of ileocolicintussusception in adults: Case report and literaturereview. World J Gastrointest Surg. 13-15.
12. Marinis A, Yiallourou A, Samanides L, et al. (2009) Intussusception of thebowel in adults: a review. World J Gastroenterol.15 (4):407-411.

13. Howard N, Pranesh N, Carter P. (2012) Intususscepção colocolônica secundária a um lipoma. Int J Surg Processo Rep.3(2):52-54.

14. Khan Z. (2017) Intussuscepção colocolônica descendente transitória devido a um grande fecaloma em um adulto. Representante do Caso ACG J. 2 de agosto de. 4:94.

15. Panagiotakis GI, Andreou AG, Petrakis IE, Tzardi M, Daskalogiannaki M, Chalkiadakis GE. (2017) Laparoscopicresection of a sigmoidcolon lipoma in a youngfemalepatient: A case report and review of theliterature. OncolLett.13(3):1303-1306.

16. Figueiredo LO, Garcia DP, Alberti LR, Paiva RA, Petroianu A, Paolucci LB, et al. (2016) Colo-colonic intussusception due to large submunous lipoma: A case of report. Int. J. Surg. Processo Rep.;28:107-110.

17. Reis L, Mendes L, Cardoso Filho C, Reis A, Arruda J. (2006) Intussuscepcão Intermitente de Lipoma de Cólon Transverso, Rev. Bras. Coloproct. 26 (4)447-448.

18. Chiba T, Suzuki S, Sato M,Tsukahara M, Saito S, Inomata M, et al. (2002) A case of a lipoma in thecoloncomplicatedbyintussusception. GastroenterolHepatol.14(6):701-702. 